\title{
Trends of Students of Home Economics at Al- Balqa Applied University Towards Home Gardening
}

\author{
Dr. Reham W. Tahtamoumi ${ }^{1}$ \\ ${ }^{1}$ Assistant Prof, Department of Applied and Social Sciences, Princess Alia University College, Al- Balqa Applied \\ University, Amman, Jordan.E mail: rehwtt@bau.edu.jo
}

\begin{abstract}
The objective of the study was to identify the trends of students of home economics at Al- Balqa Applied University toward home gardening in terms of, importance, sources of information available on this subject inside and outside the university, in addition to the most important obstacles that encounter practicing home gardening in their opinion. Also, solutions that may contribute to encouraging the practice of home gardening were investigated as well. The results of students responses showed that, home gardening is of great importance in terms of improving economic conditions and enhancing household food security with an average of (4.23 and 4.25), respectively. On the other hand, data showed that, courses included in study plan for home economics provide moderate theoretical information about home gardening (3.14), while practical part is limited (2.36). Also, responses of the students revealed a lack of laboratories and nurseries in the colleges required to apply the practical part of home gardening. Moreover, the results indicated that the students use internet to obtain information about home gardening more than the other sources available outside the university with an average of (3.32). On the other hand, students responses revealed many obstacles facing practicing home gardening, where lack of desire to practice such work (4.09) was the strongest obstacle. Meanwhile, adding more courses about home gardening to the study plan of home economics, focusing on the practical part, and providing the necessary laboratories and nurseries needed for the practical part of home gardening were the most important solutions to encourage practicing home gardening.
\end{abstract}

Keywords: Home Gardening, Home Economics, Al-Balqa Applied University.

DOI: $10.7176 / \mathrm{JBAH} / 9-3-09$

\section{Introduction}

Household agriculture is defined as those activities practiced by the individual in the cultivation of plants with a limited area of land for home, it also includes the cultivation of home surfaces and balconies, so that the plants planted in the garden will vary in size to include ornamental plants as well as medicinal plants, vegetables and fruit (Mazahra, Takhtouni, 2012).

Perhaps the most important characteristic of home farming from other agricultural activities is that it is usually practiced by family members in general, while the housewife plays the largest role in the practice and organization of this activity (Zine El Abidine, 2006).

The importance of home-based agriculture is that it provides the opportunity for family members to obtain adequate food by planting it in their garden, thus enhancing the food and economic security of the family (Oakley, 2004, Mazhara and Tahtimuni, 2012).

In addition, home-based agriculture has an important role in providing health-safe food to family members, where the use of chemicals to control agricultural pests is minimal, at a time when the world is witnessing an increase in cancer-related diseases that are heavily exposed to agricultural pesticides at all stages of their growth (Murthy et al., 1999).

Home agriculture also provides a great opportunity for the cultivation and production of medicinal plants that greatly help in the recovery of certain diseases (Engels, 2001, Zahra and Tahtamouni , 2008, Tahtamouni et al., 2015).

In addition, home-based agriculture provides a great opportunity to conserve plant genetic resources and biodiversity. Many rely on local varieties for home-based farming, which are cheaper and more adaptable to local environmental conditions, thus contributing to the conservation of local plant genetic resources (Oakaley, 2004; 
Haboubi, 2014; Tahtamouni, et al., 2016.). Household agriculture also plays a key role in the process of women's empowerment and to support her socially and economically. Studies have shown that household agriculture is practiced mostly by women in general and rural women in particular, which has contributed greatly to their economic and social standing (Finerman and Sockett, 2003).

Many studies believe that home-based farming has a significant impact in helping individuals to improve their psychological well-being two studies conducted in Britain have found that home-based agriculture has contributed to the enjoyment of daily life in individuals, helping them to discover the aesthetic sense of life and enhancing the psychological connection between man and nature (Raske, 2010; Bhatti and Church, 2004).

The subject of domestic agriculture is taught as a compulsory subject in the specialization of home economics for the bachelor's degree and diploma at Al-Balqa Applied University where the graduates in this specialization tend to work in the field of teaching in schools for all basic stages. In addition to the guidance in the branches of agriculture and home economics, where the school curriculum includes materials that look at home agriculture and the production of vegetables and fruits.

\section{Importance of study}

The importance of this study comes from the point of view of the researcher because the study is looking at the subject of home agriculture, which has a significant role in the development of individuals, especially in rural communities at the economic, health, psychological and social levels. The importance of this study lies in the fact that it is directed to students of home economics who are expected to work in teaching this field in the subjects of vocational education and home economics in schools after graduation, the researcher hopes that through this study, she will be able to identify the attitudes of female home economics students towards the field of home agriculture in terms of its importance in the community, as well as their assessment of the sources of information available to them in this field, both inside and outside the university.

The importance of this study from the point of view of the researcher as it examines the attitudes of students of home economics towards the practice of home farming by them; this is due to the scarcity of employment opportunities for graduates in general and for women graduates in particular. The unemployment rate in Jordan among males is 2017 (13.9\%) and among females (33\%) (Department of Statistics, 2017), which may make the practice of home farm an opportunity for women graduates to find a good source of income for them after graduation.

The importance of this study comes from the researcher's point of view because there are no previous studies on this subject despite its importance to society in general and to female home economics students in particular.

\section{Objectives of the study}

1. Identifying the trends of female home economics students about the importance of home agriculture.

2. Identifying the trends of female home economics students about the sources of information related to home agriculture within the university.

3. Identifying the trends of female home economics students about the sources of information related to home agriculture outside the university.

4. Identifying the trends of female home economics students towards some factors that may hinder home farming.

5. Identifying the trends of female home economics students towards some proposed solutions that may contribute to the promotion of home farming.

\section{Study Questions}

The study questionnaire was distributed among a sample of home Economics students (bachelor and diploma) at Princess Alia University College and the Irbid College for girls/ Al-Balqa Applied University where this specialization is taught exclusively in these two colleges. The questionnaire consisted of the following questions:

1. What are the trends of home economics students about the importance of home gardening?

2. What are the attitudes of female home economics students about the sources of information related to home agriculture within the university? 
3. What are the attitudes of female home economics students about the sources of information related to home agriculture outside the university?

4. What are the attitudes of female home economics students towards some of the factors that may impede home agriculture?

5. What are the attitudes of female home economics students towards some of the following suggested solutions that may contribute to improving household agriculture?

\section{Methodology of the study}

\section{Sample of the Study}

A random sample of (200) female students of bachelor and diploma were interviewed at the Princess Alia University College and Irbid University College for girls/ Al - Balqa Applied University where they were directed to the study questionnaire.

The degree of student approval for the paragraphs included in the questionnaire was estimated as follows:

$1=$ zero, 2 = limited, $3=$ medium, 4 = large, $5=$ very large.

\section{Statistical analysis of data}

Data were analyzed for all responses of sample members using SPSS program, where means and standard deviations of responses were extracted.

\section{The reliability of the study tool}

The reliability of the study instrument was verified and tested using Cronbach alpha were the reliability was $(0.85)$.

\section{The Study Domains}

1 - The spatial domain: The study members are from the provinces of Amman and Irbid as they include the colleges of Princess Alia University College and Irbid University College for girls/ Al- Balqa Applied University, Jordan, where they are specialized in teaching home economics exclusively in Jordan.

2 - Human domain: (200) female students of home economics students (bachelor and diploma) at Princess Alia University College and the Irbid University College for girls/ Al- Balqa Applied University, Jordan.

3- Age domain: Female students aged 18 years and older.

4- Time domain: The study was conducted between 20/9/2016 and 20/12/2016.

\section{Results and discussion}

Results related to the first question: "What are the attitudes of female home economics students about the importance of home farming?"

After extracting the arithmetical averages and the standard deviations of the female students regarding the trends of the home economy students towards the importance of home agriculture, it was found that the mathematical averages ranged between (3.60 - 4.25) and with standard deviations between (0.95-1.27) and with a degree of approval ranging from medium to large. Where the results showed that the students in the sample of the study see that home agriculture is an urgent need for each house under the current economic conditions significantly and with an average of 4.23 (Table 1). This result is consistent with another study on the need to resort to home agriculture to improve the economic conditions of individuals, where one study showed that home agriculture 
plays a major role in improving and ensuring the economic security of the majority of the local population in developing countries in Asia, Africa and Latin America (Galhena et al., 2013).

On the other hand, the students see that home agriculture was a source of agricultural products with a high degree of approval (4.25) (Table 1). On the other hand also, the results showed that the female students in the study sample showed that household agriculture improved the household income significantly (4.08), which is in line with the results of the study of al-Habboubi et al (2014), where they found that domestic agriculture has contributed to raising the economic income of rural and urban families In Iraq by $(3.3 \%)$.

The results of the responses of students of the home economics showed that household agriculture provides the family members with an opportunity to invest time positively, as well as developing the principle of teamwork among family members at a medium level close to the large (Table 1) this is consistent with another study conducted in Britain on the role of home agriculture in improving social cohesion by creating common interests among family members (Raske, 2010; Bhatti and Church, 2004).

Furthermore, the responses of the students in the study showed that domestic agriculture is important because it significantly promotes the issue of land and home belonging significantly (4.1). In addition, the results show that home-based agriculture provides an opportunity for female unemployed to earn income while they are within their homes at a medium level approaching large and with an average of 3.6 (Table 1). Another study on this subject shows that home-based agriculture has provided a job opportunity and a good source of income for women, especially in some developing countries where a social system prevails that restricts women from working outside their home (Oakley, 2004).

Table 1: Trends of home economics students towards the importance of home agriculture

\begin{tabular}{|c|c|c|c|}
\hline Number & Paragraph & $\begin{array}{l}\text { *Arithmetic } \\
\text { average }\end{array}$ & $\begin{array}{l}\text { Standard } \\
\text { deviation }\end{array}$ \\
\hline 1 & $\begin{array}{l}\text { Home agriculture is an urgent necessity for } \\
\text { every household in the current economic } \\
\text { conditions. }\end{array}$ & 4.23 & 1.068 \\
\hline 2 & $\begin{array}{l}\text { Home agriculture provides agricultural } \\
\text { products that are food-safe. }\end{array}$ & 4.25 & 0.959 \\
\hline 3 & $\begin{array}{l}\text { Household agriculture improves household } \\
\text { income. }\end{array}$ & 4.08 & 1.038 \\
\hline 4 & $\begin{array}{l}\text { Home farming allows family members the } \\
\text { opportunity to invest time positively. }\end{array}$ & 3.68 & 1.007 \\
\hline 5 & $\begin{array}{l}\text { Home farming develops the principle of } \\
\text { teamwork among family members. }\end{array}$ & 3.85 & 1.112 \\
\hline 6 & $\begin{array}{l}\text { Home agriculture promotes the issue of } \\
\text { belonging to the land and the house. }\end{array}$ & 4.01 & 1.148 \\
\hline 7 & $\begin{array}{l}\text { Home-based agriculture provides an } \\
\text { opportunity for female unemployed to earn } \\
\text { income while in their homes. }\end{array}$ & 3.60 & 1.278 \\
\hline
\end{tabular}

* The degree of approval of the students was estimated, on the paragraphs included in the questionnaire as follows:

$1=$ zero, 2 = limited, 3 = medium, 4 = large, 5 = very large.

Results related to the second question: "What are the attitudes of female home economics students about the sources of information related to home agriculture within the university? 
Table (2a) shows the results of the responses of female home economics students about the sources of information on home agriculture within the university, where the results of the students in the sample of the study showed that the subjects included in the Home Economics Study Plan provide information on household agriculture at a moderate level (3.14). It is interesting to note that the students in the study evaluated the level of materials studied in home agriculture, which are included in the plan of home economics in terms of number, in addition to the extent of the emphasis on the practical side, with an average of (2.62 and 2.36) respectively (Table 2a) which requires a review of the materials taught within the study plan for home economics in this area. With the knowledge that the study plan for home economics currently in place at Al-Balqa University includes only one course teaching home agriculture.

The results showed that according to the students in the study sample that the laboratories and nurseries where the practical aspect is applied in relation to household agriculture are unfortunately available with a minimum of (1.51) (Table 2a). As for the library of the college, it was found that the female students went to the library to obtain information about home agriculture with a limited degree (2.10) also, the availability of books on home agriculture within the library, as well as the level of information provided by these books on home agriculture (2.57 and 2.41, respectively) (Table 2a), which will negatively affect the efficiency of students who will work in the future in the teaching of school students, courses in the field of agriculture both theoretically and practically.

Table 2a: Trends of Female Home Economics' Students on the Sources of Information on Home Agriculture within the University

\begin{tabular}{|c|c|c|c|}
\hline Number & Item & Mean & $\begin{array}{l}\text { Standard } \\
\text { deviation }\end{array}$ \\
\hline 1 & $\begin{array}{l}\text { The subjects included in the Home agriculture } \\
\text { Study Plan provide information on home } \\
\text { agriculture }\end{array}$ & 3.14 & 1.047 \\
\hline 2 & $\begin{array}{l}\text { The number of subjects taught in home } \\
\text { agriculture contained in the Home Economics } \\
\text { Plan is sufficient }\end{array}$ & 2.62 & 0.9961 \\
\hline 3 & $\begin{array}{l}\text { The materials that teach home agriculture are } \\
\text { focused on the home economy plan on the } \\
\text { practical side. }\end{array}$ & 2.36 & 1.088 \\
\hline 4 & $\begin{array}{l}\text { The College offers laboratories and nurseries } \\
\text { where the practical aspect of home agriculture } \\
\text { is applied }\end{array}$ & 1.51 & 0.956 \\
\hline 5 & $\begin{array}{l}\text { You go to the university library to get } \\
\text { information on home agriculture }\end{array}$ & 2.10 & 1.062 \\
\hline 6 & $\begin{array}{l}\text { The University Library offers special books on } \\
\text { home agriculture }\end{array}$ & 2.57 & 0.918 \\
\hline 7 & $\begin{array}{l}\text { Books on home agriculture in the university } \\
\text { library provide information on home } \\
\text { agriculture }\end{array}$ & 2.41 & 0.916 \\
\hline
\end{tabular}

* The degree of approval of the students was based on the paragraphs included in the questionnaire as follows: 1 = zero, 2 = limited, 3 = medium, 4 = large, 5 = very large.

Results related to the third question: What are the attitudes of female home economics students about the sources of information related to home agriculture outside the university?

The results of the statistical analysis of Table $2 b$ show that the Internet is one of the main sources of information used by home economics students to obtain information about home agriculture and to a medium degree (3.32). While the responses of the students in the study showed that they resorted to a limited degree to the rest of the sources included in the questionnaire of the study, which included academics in the field of home farming and farmers, in addition to television programs and foreign books, with an average of between (2.24 2.69), where farmers' access to information about domestic agriculture was ranked as the last as a source for information (Table 2b). The students' access to the Internet may be attributed to the Internet as a source of information because of the ease of access to information compared to the rest of the proposed sources, although 
the other sources provide the correct information about home agriculture and scientifically compared to what the Internet offers, these resources also provide the opportunity for students to obtain scientific and practical experience from their accredited sources, in addition to the possibility of discussing and asking questions, which is unable to provide the Internet properly.

The results also showed that local television provides programs on home-based agriculture with a limited level approaching the middle (2.69) which requires the programmers to do more to provide these programs because of the great benefit to the members of the community, including farmers and students as they provide the correct information about home agriculture and reach the largest segment of the community without the need to bear the financial burden of the subscription The Internet.

Table 2b: Trends of domestic economics students on sources of information related to home agriculture outside the university

\begin{tabular}{|c|c|c|c|}
\hline Number & Item & Mean & $\begin{array}{l}\text { Standard } \\
\text { deviation }\end{array}$ \\
\hline 1 & $\begin{array}{l}\text { You use the Internet to get information about } \\
\text { home agriculture }\end{array}$ & 3.32 & 1.337 \\
\hline 2 & $\begin{array}{l}\text { You go to academic specialists to get } \\
\text { information on home agriculture }\end{array}$ & 2.41 & 1.030 \\
\hline 3 & $\begin{array}{l}\text { You go to farmers to get information about } \\
\text { home agriculture }\end{array}$ & 2.24 & 1.116 \\
\hline 4 & $\begin{array}{l}\text { You watch television programs to get } \\
\text { information about home agriculture }\end{array}$ & 2.46 & 1.065 \\
\hline 5 & Local TV offers programs on home agriculture & 2.69 & 0.937 \\
\hline 6 & $\begin{array}{l}\text { You use books from outside the Home } \\
\text { Economics specialty to get information } \\
\text { about home farming }\end{array}$ & 2.47 & 1.116 \\
\hline
\end{tabular}

Results related to the fourth question: What are the attitudes of female home economics students towards some of the factors that may impede home agriculture?

The results showed that the factors included in the study questionnaire hinder household farming, but to varying degrees from the point of view of the students in the sample. The results showed that the lack of desire to practice home agriculture is the biggest obstacle to the practice of home agriculture from their point of view, with a high degree of approval (4.09) as clear in (Table 3), while the second was the lack of a social environment in support of agricultural work for girls with a medium approval level approaching the large (3.81). This is consistent with the results of two similar studies conducted in the Philippines and Bangladesh, respectively, where social factors have been a major impediment to domestic farming in these countries (Miura et al., 2003, Talukderet al.2000, Galhena et al., 2013).

On the other hand, the students in the research sample found that the absence of private markets for the marketing of home agricultural products constitutes a handicap for working in household agriculture with a limited degree (2.13) (Table 3). In contrast to the results of another study conducted in Latin America, where the lack of private markets to market home agricultural products has been the biggest obstacle to home-based farming in these countries (Howard, 2006). on the other hand, the rest of the proposed factors were obstacles to working in household agriculture, with a medium grade ranging from (3.0 and 3.22) as shown in Table 3.

For example, the students in the sample of the study found that the lack of availability of land area in addition to the lack of the ability to purchase agricultural inputs hindered the work of home agriculture with a medium degree (3.2) while another study found that the lack of both workers hampered the work of home farming very significantly (Fernandes and Nair, 1986). 
Table 3: Trends of home Economics Students towards Some Factors that hinder Work in Home Agriculture

\begin{tabular}{|c|c|c|c|}
\hline Number & Item & Mean & $\begin{array}{l}\text { Standard } \\
\text { deviation }\end{array}$ \\
\hline 1 & Lack of land area & 3.22 & 1.417 \\
\hline 2 & $\begin{array}{l}\text { Lack of capacity to purchase agricultural } \\
\text { inputs }\end{array}$ & 3.20 & 1.201 \\
\hline 3 & Lack of agricultural inputs & 3.00 & 1.171 \\
\hline 4 & $\begin{array}{l}\text { Lack of sufficient knowledge about home } \\
\text { agriculture }\end{array}$ & 3.10 & 1.020 \\
\hline 5 & $\begin{array}{l}\text { Lack of sources of information on home } \\
\text { agriculture }\end{array}$ & 3.04 & 1.029 \\
\hline 6 & $\begin{array}{l}\text { Lack of desire to practice household } \\
\text { agriculture }\end{array}$ & 4.09 & 1.287 \\
\hline 7 & Lack of time to practice home farming & 3.01 & 1.175 \\
\hline 8 & $\begin{array}{l}\text { Lack of a supportive social environment for } \\
\text { agricultural work for girls }\end{array}$ & 3.81 & 1.193 \\
\hline 10 & $\begin{array}{l}\text { Lack of private markets to market domestic } \\
\text { agricultural products }\end{array}$ & 2.13 & 1.130 \\
\hline 11 & $\begin{array}{l}\text { Lack of government support for small } \\
\text { projects related to household agriculture }\end{array}$ & 3.02 & 1.304 \\
\hline
\end{tabular}

* The degree of approval of the students was based on the paragraphs included in the questionnaire as follows: 1 $=$ zero, 2 = limited, 3 = medium, $4=$ large, 5 = very large

Results related to the fifth question: What are the attitudes of female home economics students towards some of the following suggested solutions that may contribute to improving household agriculture?

The results of the responses of the students in the sample of the study showed that the degree of their agreement with the solutions proposed in the questionnaire, which may contribute to the improvement of home farming, ranged from the middle to the large to close to large and large degree and with averages ranging between (3.62- 4.11) Table 4.

Where the results showed that students are moving more towards solutions to improve their knowledge skills about home agriculture through their academic studies at the university in particular, where the students considered that the plan of home economy include more materials that look at home agriculture in addition to focusing on the practical aspect of the subjects that teach home agriculture within the specialization of home economics and the provision of laboratories, nurseries and the necessary infrastructure to provide students with the practical application of materials related to home agriculture solutions that may contribute to the improvement of household agriculture to a large extent (Table 4).

The students also see that providing the university library with modern books on home agriculture contributes to the improvement of household agriculture with a medium level of close to large (3.87). on the other hand, it is clear from the results that the encouragement of the unemployed, especially females, to practice domestic agriculture within their homes to obtain a financial income and the presence of governmental and private bodies contribute to providing material and cognitive encouragement for female in the practices of home agriculture may contribute to the improvement of domestic agriculture with a medium to large degree (Table 4), which is consistent with previous reports showing that government and international women are encouraged to work in agriculture has contributed to making women account for $40 \%$ of agricultural employment in Latin America while encouraging women to make up $60-80 \%$ of agricultural employment in Africa and Asia which has contributed to raising the income of these women in difficult economic and social conditions in which limited employment opportunities and preference for male employment on females (Zine El Abidine, 2006). 
Table 4: Trends of Domestic Economy Students towards some of the following suggested solutions that may contribute to encouraging the practice of domestic agriculture

\begin{tabular}{lllc}
\hline Number & Item & Mean & $\begin{array}{c}\text { Standard } \\
\text { deviation }\end{array}$ \\
\hline $\mathbf{1}$ & $\begin{array}{l}\text { The home economy plan should include more } \\
\text { materials that look at home agriculture }\end{array}$ & 4.10 & $\mathbf{1 . 1 9 4}$ \\
$\mathbf{2}$ & $\begin{array}{l}\text { Focus on the practical aspect of the subjects } \\
\text { taught in home farming }\end{array}$ & 4.01 & $\mathbf{1 . 2 3 8}$ \\
$\mathbf{3}$ & $\begin{array}{l}\text { Providing laboratories, nurseries and necessary } \\
\text { infrastructure that provide students with the } \\
\text { practical application of subjects related to } \\
\text { home agriculture }\end{array}$ & 4.11 & $\mathbf{1 . 4 9 3}$ \\
$\mathbf{5}$ & $\begin{array}{l}\text { Providing the university library with modern } \\
\text { books on home agriculture } \\
\text { The existence of governmental and civil } \\
\text { bodies that contribute to the provision of } \\
\text { material and cognitive encouragement to } \\
\text { female practices of home agriculture } \\
\text { Government agencies should provide popular } \\
\text { markets for home agricultural products } \\
\text { Encouraging those who are unemployed, } \\
\text { especially females, to practice home } \\
\text { agriculture inside their homes to obtain a } \\
\text { financial income }\end{array}$ & 3.87 & $\mathbf{1 . 2 5 6}$ \\
$\mathbf{6}$ & $\begin{array}{l}\text { Improving the role of the audiovisual media } \\
\text { in relation to programs on home agriculture }\end{array}$ & 3.64 & $\mathbf{1 . 2 9 2}$ \\
$\mathbf{7}$ & $\mathbf{3 . 6 9}$ & $\mathbf{1 . 2 4 2}$ \\
\hline $\mathbf{8}$ & $\mathbf{1 . 2 0 5}$ \\
\hline
\end{tabular}

* The degree of approval of the students on the paragraphs, which included the questionnaire, was estimated as follows: 1 = zero, 2 = limited, 3 = medium, 4 = large, 5 = very large.

\section{Conclusions and Recommendations}

The results of the study show that students of the home economy who were included in the study they believe that home agriculture is of great importance and plays an important role in improving economic conditions and enhancing food security for families.

They believe that home agriculture is of great importance and plays an important role in improving economic conditions and enhancing food security for families. On the other hand, the results showed a clear shortage in the sources and quality of education both theoretical and practical in the field of home agriculture within the university. The results also show that the students see that there are many obstacles to the practice of home farming; the most important from their point of view is the lack of desire to practice agricultural work.

Based on the results, the researcher believes that the Balqa Applied University a thorough review of the teaching plan for the specialization of home economics with regard to the material of home agriculture both theoretical and practical and provide the infrastructure of laboratories and nurseries To promote the empowerment of female students to acquire the scientific and practical skills required by this field, in addition to the inclusion of additional material on the production of vegetables and fruit domestically and not only the production of ornamental plants as in the couse currently taught to students.

The researcher also believes that the university can play a large role in encouraging female students to practice home farming through holding seminars on this subject, in which successful female models are hosted, who have worked in the field to inform the students about their experiences in this field, in addition to organizing scientific trips to some of the leading home gardens in the field of home agriculture. 
References

Bhatti M. and Church A.(2004). Home, the culture of nature and the meanings of gardens in late modernity.Housing StudiesJournal. 19 (1):37-51.

Department of Statistics (2017). First Quarter Report on Unemployment Rate in the Hashemite Kingdom of Jordan. Amman - Jordan.

Engels J. (2001).Home gardens - a genetic resources perspective. International Plant Genetic Resources Institute, (IPGRI). Pp: 3-10.

Fernandes E. C. M. , Nair P. K. R. (1986). An evaluation of the structure and function of tropical homegardens.Agr Syst. 21:279-310.

Finerman R. and Sackett R. ( 2003 ). Using Home Gardens to Decipher Health and Healing in the Andes.Medical Anthropology Quarterly.17 (4): 459-482.

Galhena D. H, Freed R.andMaredia K.M. (2013). Home gardens: a promising approach to enhance household food security and wellbeing. Agriculture \& Food Security. 2: 8-9

Haboubi, A., Clemens, P., Dario, D., Abdul Hussein, A., Jannah Ferguson, R. Talera, Thiones van, R. (2014). Agriculture for the sake of -Development in Iraq. International Food Policy Research Institute, Washington. P: 1-5.

Howard P.L. (2006). Gender and social dynamics in Sweden and home gardens in Latin America. In Tropical Homegardens: A Time-Tested Example of Sustainable Agroforestry. Springer Science.Nair BMKPKR. Heidelberg, The Netherlands.

Mazahreh, A. Tahtamouni, R. (2012). Ornamental plants and landscaping. Dar Qandil Publishing, Amman, Jordan. P 6-8.

Miura S., Osamu K., Susumu W. (2003). Home gardening in urban poor communities of the Philippines.Int J Food SciNutr . 54(1):77-88.

Murthy P.V. S., Lakshmi K.V., Bamji M.S. (1999). Impact of home gardening and nutrition education in a district of rural India .World Health Organization publications. 77 (9): 12-23

Oakley E. (2004). Home gardens: a cultural responsibility. LEISA Magazine. India. Pp: 22-23

RaskeM. (2010). Nursing Home Quality of Life: Study of an Enabling Garden. Journal of Gerontological Social Work. 53(4): 336-351.

Tahtamouni, R. \& Mazahreh, A. (2008). A study about Jordanian women's knowledge of medicinal plants at different age, educational and residential levels, An-Najah National University Journal. 22 (1): 347- 276.

Tahtamouni, R., Shibli R.A, Al- Abdallat A.M. ,. Al- Qudah T.S., Younis L., Al-Baba H. and Al- Ruwaiei H. (2015). In Vitro Conservation and Cryopreservation of Medicinal and Aromatic Plants: A Review.Jordan Journal of Agricultural Sciences. 11 (1): 147-167.

Tahtamouni R., Shibli R.A, Al- Abdallat A.M. ,. Al- Qudah T.S.(2016). Analysis of growth, oil yield, and carvacrol in ThymbraspicataL. after slow-growth conservation.Turkish Journal of Agriculture and Forestry (TUBITTAK).40: 213-221

Talukder A., Kiess L., Huq N., de Pee S., Darnton-Hill I., Bloem M.W. (2000). Increasing the production and consumption of vitamin A-rich fruits and vegetables: lessons learned in taking the Bangladesh homestead gardening program to a national scale.Food Nutr Bull. 21(2):165-172.

Zain Alabidin, I. (2006). Evaluation of rural women's schools in developing the capabilities of women in the technology of organic farming of zucchini crop in the village of Shibairat. Sudan University of Science and Technology. P. 15-18. 